Prepared in Cooperation with The Nature Conservancy

\title{
Simulated Effects of Groundwater Pumping and Artificial Recharge on Surface-Water Resources and Riparian Vegetation in the Verde Valley Sub-Basin, Central Arizona
}

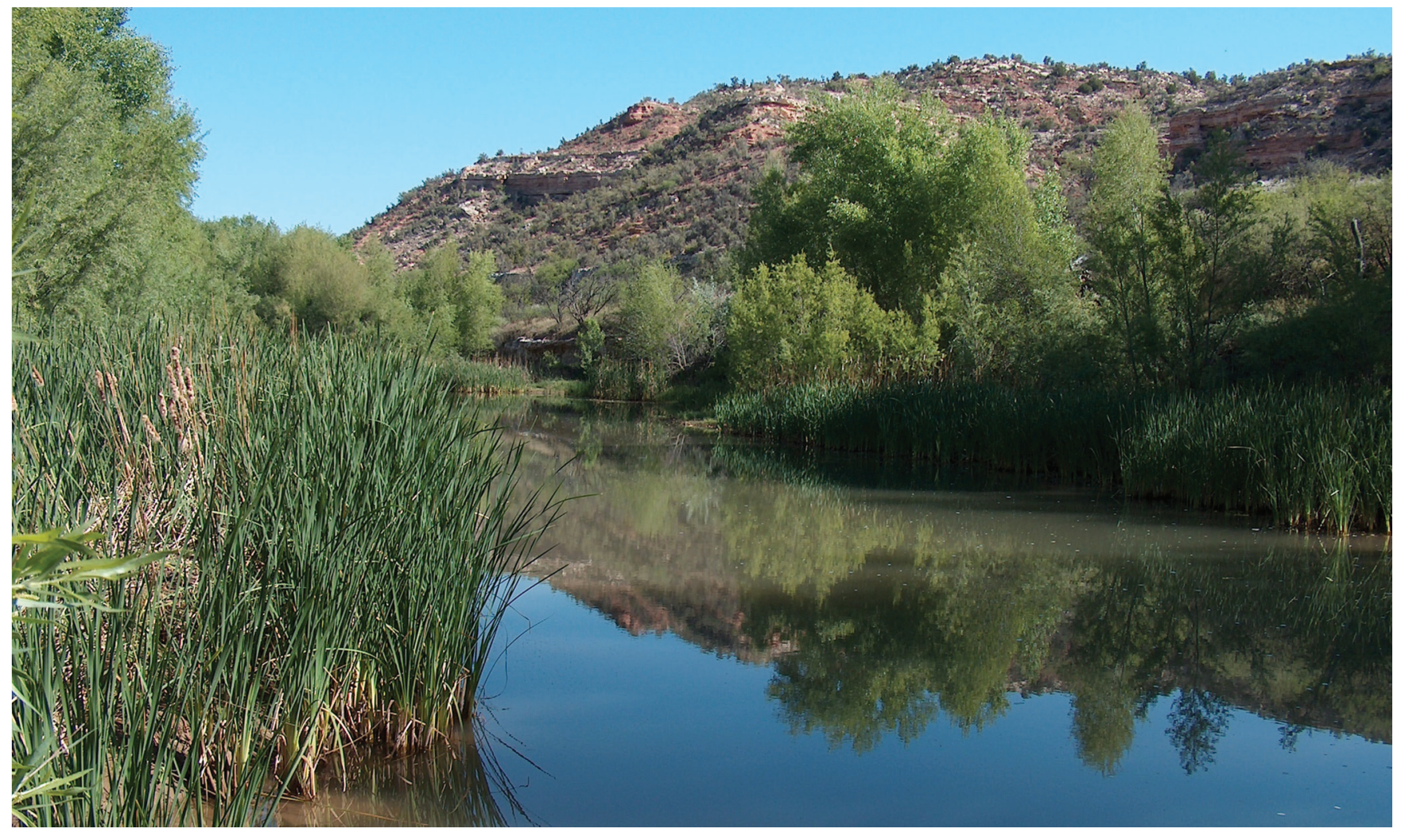

Scientific Investigations Report 2010-5147 
COVER: Verde River Greenway below Deadhorse Ranch State Park, Cottonwood, Arizona. Courtesy of Jeanmarie Haney, The Nature Conservancy. 


\section{Simulated Effects of Groundwater Pumping and Artificial Recharge on Surface-Water Resources and Riparian Vegetation in the Verde Valley Sub-Basin, Central Arizona}

By Stanley A. Leake and Donald R. Pool

Prepared in Cooperation with The Nature Conservancy

Scientific Investigations Report 2010-5147 


\section{U.S. Department of the Interior \\ KEN SALAZAR, Secretary}

\section{U.S. Geological Survey \\ Marcia K. McNutt, Director}

\section{U.S. Geological Survey, Reston, Virginia 2010}

This report and any updates to it are available online at:

http://pubs.usgs.gov/sir/2010/5147/

For more information on the USGS - the Federal source for science about the Earth, its natural and living resources, natural hazards, and the environment, visit http://www.usgs.gov or call 1-888-ASK-USGS (1-888-275-8747)

For an overview of USGS information products, including maps, imagery, and publications, visit http://www.usgs.gov/pubprod

To order this and other USGS information products, visit http://store.usgs.gov

Any use of trade, product, or firm names is for descriptive purposes only and does not imply endorsement by the U.S. Government.

Although this report is in the public domain, permission must be secured from the individual copyright owners to reproduce any copyrighted material contained within this report.

Suggested citation:

Leake, S.A., and Pool, D.R., 2010, Simulated effects of groundwater pumping and artificial recharge on surface-water resources and riparian vegetation in the Verde Valley sub-basin, Central Arizona: U.S. Geological Survey Scientific Investigations Report 2010-5147, 18 p. 


\section{Contents}

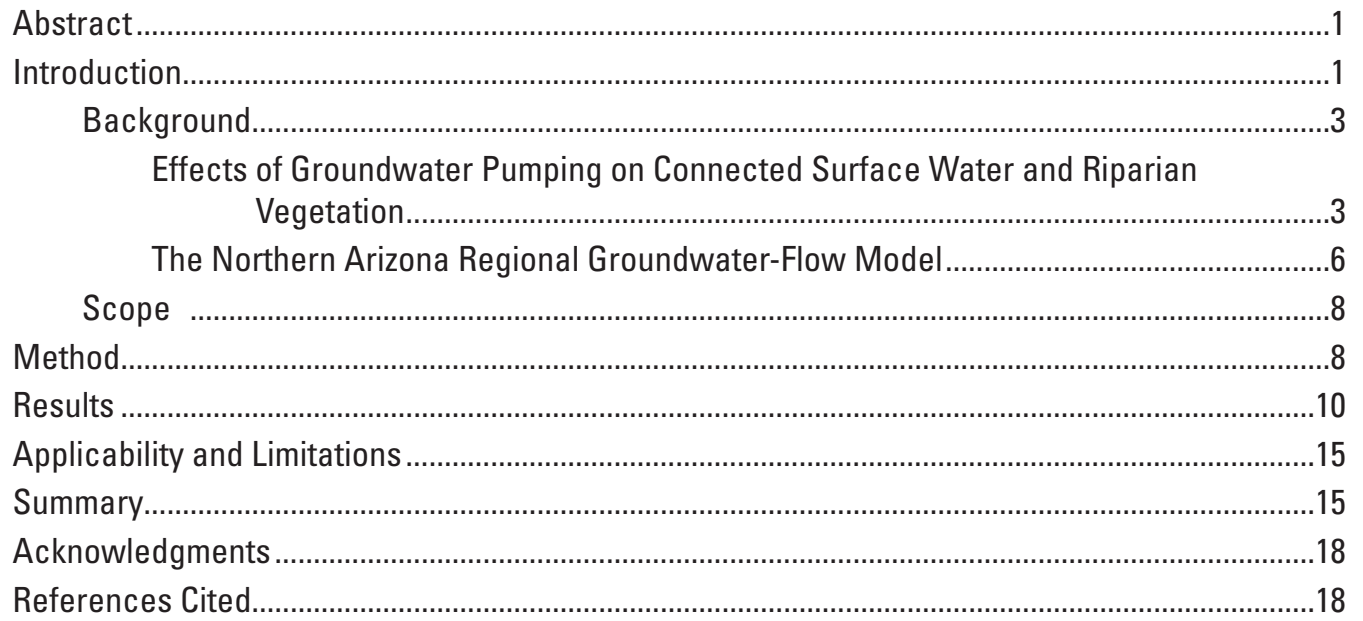

\section{Figures}

1. Verde Valley sub-basin and relation to the extent of the Northern Arizona Regional Groundwater-Flow Model.

2. Groundwater withdrawal rates in the Verde Valley sub-basin from 1950-2006 simulated in the model by Pool and others (in press).

3. Stages of effects of a pumping well on a nearby stream. $(A)$ A cone of depression has developed around the well, but groundwater still discharges to the stream. $(B)$ After some time, the cone of depression has deepened and spread to the nearby stream, resulting in elimination of groundwater discharge to the stream and further loss of water in the stream to the aquifer. $(\mathcal{C})$ When the stream cannot supply the quantity of water pumped, the stream may eventually lose all of its water to the aquifer and become ephemeral and nearby riparian vegetation also may be affected. Modified from Webb and others (2007).

4. Sources of water to a pumped well through time...............................................................5

5. Conceptualized relations among hydrogeologic units and Northern Arizona Regional Groundwater-Flow Model layers in the Verde Valley sub-basin. Volcanic rocks and the lower Supai Group are confining units. Modified from Pool and others (in press)..........6

6. Active unconfined and confined model cells in the Northern Arizona Regional Groundwater-Flow Model within the Verde Valley sub-basin for model layers 1, 2, and 3..........7

7. Decrease in surface-water flow and evapotranspiration for the example shown in figure 4 for a well that pumps 30 acre-feet per year for years 1-5; then for years 6-10 the pumping rate continues (case 1), stops (case 2), and doubles (case 3).

8. Computed reduction in flow of streams and springs and reduction in riparian evapotranspiration as a fraction of pumping rate that would result from pumping groundwater from model layer 1 at a constant rate for 10 years. 
9. Computed reduction in flow of streams and springs and reduction in riparian evapotranspiration as a fraction of pumping rate that would result from pumping groundwater from model layer 1 at a constant rate for 50 years.

10. Computed reduction in flow of streams and springs and reduction in riparian evapotranspiration as a fraction of pumping rate that would result from pumping groundwater from model layer 2 at a constant rate for 10 years.

11. Computed reduction in flow of streams and springs and reduction in riparian evapotranspiration as a fraction of pumping rate that would result from pumping groundwater from model layer 2 at a constant rate for 50 years.

\section{Tables}

1. Statistics of aquifer properties and saturated thickness simulated in the part of the Northern Arizona Regional Groundwater-Flow Model that underlies the Verde Valley sub-basin. Values are for active parts of each model layer.

2. Example calculations of absolute depletion from depletion fractions for a well that pumps 30 acre-feet per year for years $1-5$, and then continues pumping at that rate for years $6-10$ (case 1 ), shuts off for years $6-0$ (case 2), and doubles in pumping rate for years $6-10$ (case 3 )

3. Average depletion after 100 years of pumping expressed as a fraction of the pumping rate for features simulated with the Drain, Evapotranspiration, and Stream Packages, for pumping locations in layers 1,2 , and 3. 


\section{Conversion Factors}

\begin{tabular}{lcl}
\hline \multicolumn{1}{c}{ Multiply } & By & To obtain \\
\hline foot (ft) & Length & \\
mile (mi) & 0.3048 & meter $(\mathrm{m})$ \\
\hline & 1.609 & kilometer $(\mathrm{km})$ \\
\hline square mile $\left(\mathrm{mi}^{2}\right)$ & Area & \\
\hline & 2.590 & square kilometer $\left(\mathrm{km}^{2}\right)$ \\
\hline acre-foot per year (acre-ft/yr) & Flow rate & \\
gallon per minute (gal/min) & 1,233 & cubic meter per year $\left(\mathrm{m}^{3} / \mathrm{yr}\right)$ \\
\hline & 0.06309 & liter per second $(\mathrm{L} / \mathrm{s})$ \\
\hline foot per day (ft/d) & Hydraulic conductivity & \\
\hline per foot (1/ft) & 0.3048 & meter per day $(\mathrm{m} / \mathrm{d})$ \\
\hline
\end{tabular}

Vertical coordinate information is referenced to the "North American Vertical Datum of 1988 (NAVD 88)."

Horizontal coordinate information is referenced to the "North American Datum of 1927 (NAD 27)."

Altitude, as used in this report, refers to distance above the vertical datum. 


\title{
Simulated Effects of Groundwater Pumping and Artificial Recharge on Surface-Water Resources and Riparian Vegetation in the Verde Valley Sub-Basin, Central Arizona
}

\author{
By Stanley A. Leake and Donald R. Pool
}

\begin{abstract}
In the Verde Valley sub-basin, groundwater use has increased in recent decades. Residents and stakeholders in the area have established several groups to help in planning for sustainability of water and other resources of the area. One of the issues of concern is the effect of groundwater pumping in the sub-basin on surface water and on groundwaterdependent riparian vegetation. The Northern Arizona Regional Groundwater-Flow Model by Pool and others (in press) is the most comprehensive and up-to-date tool available to understand the effects of groundwater pumping in the sub-basin. Using a procedure by Leake and others (2008), this model was modified and used to calculate effects of groundwater pumping on surface-water flow and evapotranspiration for areas in the sub-basin. This report presents results for the upper two model layers for pumping durations of 10 and 50 years. Results are in the form of maps that indicate the fraction of the well pumping rate that can be accounted for as the combined effect of reduced surface-water flow and evapotranspiration. In general, the highest and most rapid responses to pumping were computed to occur near surface-water features simulated in the modified model, but results are not uniform along these features. The results are intended to indicate general patterns of model-computed response over large areas. For site-specific projects, improved results may require detailed studies of the local hydrologic conditions and a refinement of the modified model in the area of interest.
\end{abstract}

\section{Introduction}

The study area includes the "Verde Valley sub-basin," as designated by the Arizona Department of Water Resources (http://www.azwater.gov/azdwr/StatewidePlanning/ RuralPrograms/OutsideAMAs_PDFs_for_web/documents/ verde_river.pdf, accessed April 25, 2010). The area lies mostly within the transition zone between the Basin and Range lowlands to the south and the Colorado Plateau to the north (fig. 1). Land-surface altitudes range from about $2,900 \mathrm{ft}$ where the Verde River leaves the sub-basin, to about 12,600 ft near the northernmost point on the boundary of the sub-basin. Perennial flow of surface water occurs in the Verde River and reaches of Sycamore Creek, Oak Creek, Wet Beaver Creek, and West Clear Creek. Major vegetation types are desert scrub at lower altitudes, piñon-juniper woodlands at intermediate altitudes, and conifer forests at higher altitudes. Along the surface-water channels in the Verde Valley sub-basin, some of the more common native species of woody riparian vegetation are Frémont cottonwood, mesquite, sycamore, ash, black willow, seepwillow, coyote willow, and Arizona alder (Webb and others, 2007). These and other plants that use groundwater generally occur in narrow bands, commonly within tens to hundreds of feet of stream banks.

Population estimates for July 1, 2008 for incorporated cities and towns in the sub-basin (http://www.census.gov/popest/ cities/tables/SUB-EST2008-04-04.csv, accessed March 19, 2010) include 11,599 in Sedona, 11,412 in Cottonwood, 10,849 in Camp Verde, 4,263 in Clarkdale, and 353 in Jerome. These data suggest that average annual population growth rates from 2000 to 2008 for these cities and towns range from about 1 to more than 3 percent. Unincorporated areas of the sub-basin, including communities of Cornville and Rimrock and privately owned rural areas, also are populated. Average annual population growth for the entire sub-basin likely has been 1.5 percent or higher since 2000. If that growth rate were maintained, population would double in about 28 years. The larger cities of Flagstaff and Prescott with estimated 2008 populations of 60,222 , and 42,697 , respectively, are in areas adjacent to the sub-basin.

Although surface water is diverted from the Verde River for irrigation, nearly all water for public, domestic, and industrial supplies is groundwater (Blasch and others, 2006). Groundwater pumping occurs beneath more populated parts of the sub-basin in hydrogeologic units that comprise shallow alluvium along streams, fluviolacustrine basin fill, sandstone and carbonate sediments, and fractured crystalline rocks. Decadal estimates of groundwater withdrawals used in the groundwater model by Pool and others (in press) suggest a 


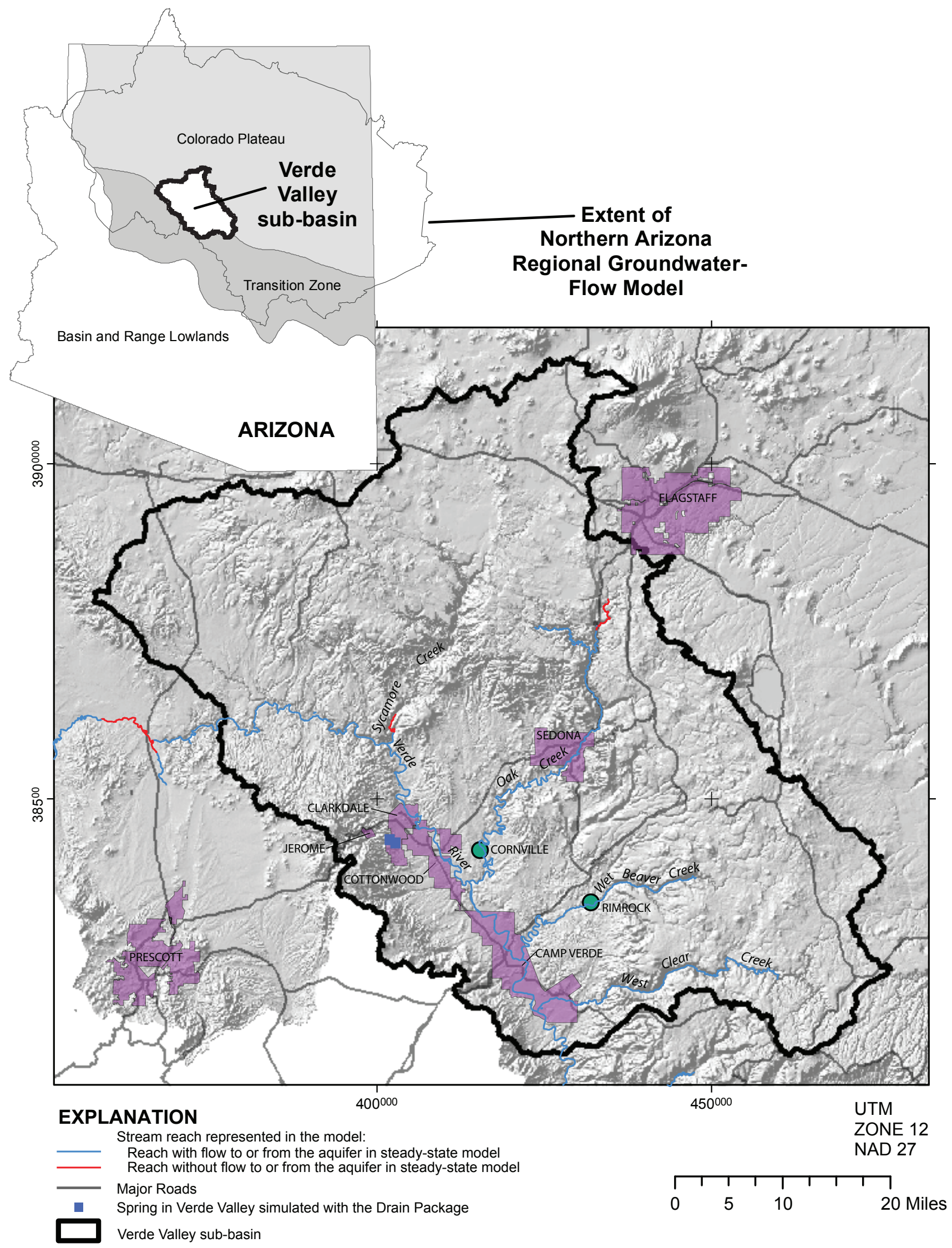

Figure 1. Verde Valley sub-basin and relation to the extent of the Northern Arizona Regional Groundwater-Flow Model. 
greater than ten-fold increase in groundwater use in the subbasin in the latter half of the 20th century (fig. 2).

With increasing population and water use, sustainability of water resources and long-term health of the Verde River is a concern of many residents of the sub-basin. Several groups of stakeholders are considering strategies for sustainability of water supplies in the Verde Valley sub-basin and adjacent areas. This report provides analyses that can help water managers and others understand long-term effects of groundwater withdrawals on the Verde River and adjacent groundwaterdependent vegetation.

\section{Background}

Winter and others (1998) characterize groundwater and surface water as being a single resource. Development of groundwater affects connected surface-water resources and development of surface-water resources affects connected groundwater resources. This report addresses general aspects of how groundwater pumping affects surface water and evapotranspiration, and presents an overview of the Northern Arizona Regional Groundwater-Flow Model (Pool and others, in press) as a tool for studying interaction of groundwater and surface water in the Verde Valley sub-basin.

\section{Effects of Groundwater Pumping on Connected Surface Water and Riparian Vegetation}

In an aquifer system such as the one that underlies the Verde Valley sub-basin, the principal source of groundwater is recharge from precipitation and snowmelt that percolates to the water table. In much of the southwestern United States, recharge tends to be focused in stream channels where permeable sediments allow water to infiltrate (Stonestrom and others, 2007). Water moves through the aquifer system and eventually discharges at lower elevations to springs, streams, rivers, and by evapotranspiration in areas of vegetation that use groundwater. The general term "evapotranspiration" includes evaporation and transpiration of water in shallow soil, as well as from the saturated groundwater system. In the context of this report, however, "evapotranspiration" refers to use of water from the saturated groundwater system by vegetation.

The potential energy in an aquifer system is characterized by the groundwater level, sometimes referred to as the "head." In an unconfined aquifer system, the potential energy is characterized by the elevation of the water table. The slope of the potential-energy surface at any point is the groundwater "gradient." Groundwater levels are determined through measurements of water levels in wells, and groundwater gradients and directions of movement are estimated by using measurements of water levels from a number of wells in different parts of the aquifer system. Groundwater moves down-gradient from areas of higher water levels to areas of lower water levels. The presence of gradients indicates that groundwater is moving from areas of recharge or inflow to areas of discharge. The rates of groundwater movement vary greatly among aquifer systems. Under natural or "predevelopment" conditions, rates of recharge to and discharge from an aquifer system vary seasonally and interannually with varying climate, but when viewed as long-term averages, commonly are assumed to be equal. The equilibrium condition of equal recharge and discharge with no change in groundwater levels is referred to as "steady state."

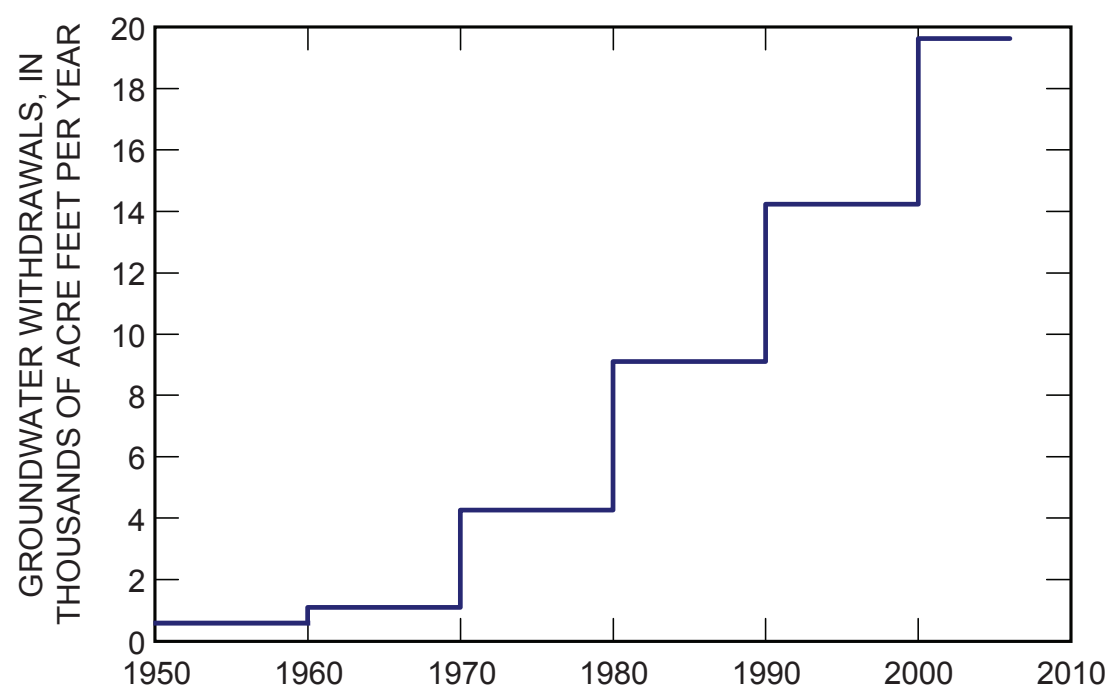

Figure 2. Groundwater withdrawal rates in the Verde Valley sub-basin from 1950-2006 simulated in the model by Pool and others (in press). 
Removal of groundwater by wells initiates changes to an aquifer system with effects that are variable through time. When water is initially pumped from a well, all of the water comes from storage around the well. A cone of depression develops around the well and the gradient of the groundwater head is the driving force for movement of water into the well. If the aquifer is unconfined, nearly all of the storage change is from draining of pore spaces at the water table. This resulting cone of depression can be thought of as a lowering of the water table around the well, with the greatest decline in the water table at the location of the well (fig. $3 A$ ). If the aquifer is confined, the change in storage is the combined effect of reduction of the sizes of pore spaces and expansion of water that results from decreasing the fluid pressure in the aquifer.
This resulting cone of depression is an area of decreased fluid pressure around the well, with the greatest decrease in fluid pressure at the well.

As pumping continues, the cone of depression expands to increasing distances from the well. When the cone of depression expands into areas with streams (fig. $3 B$ ), wetlands, rivers, and lakes that are in hydraulic connection with the aquifer, and areas of vegetation that use groundwater, the natural gradients that drive the exchange of groundwater between the aquifer and these features are altered. For surface-water features that under natural conditions lose water to the aquifer, the cone of depression from a well can increase the gradients from those features; and for surface-water features that gain water from the aquifer, the cone of depression
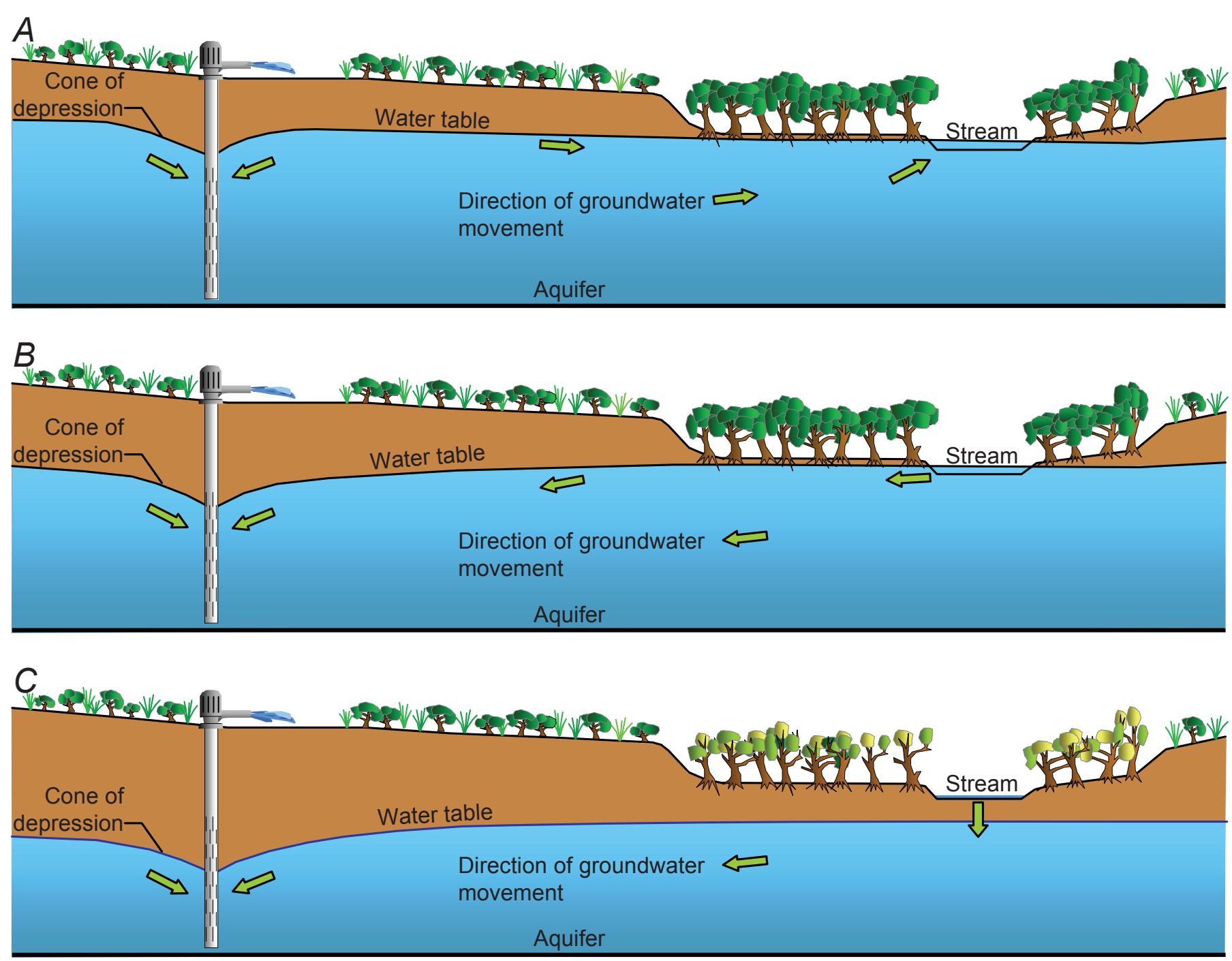

Figure 3. Stages of effects of a pumping well on a nearby stream. $(A)$ A cone of depression has developed around the well, but groundwater still discharges to the stream. $(B)$ After some time, the cone of depression has deepened and spread to the nearby stream, resulting in elimination of groundwater discharge to the stream and further loss of water in the stream to the aquifer. $(C)$ When the stream cannot supply the quantity of water pumped, the stream may eventually lose all of its water to the aquifer and become ephemeral and nearby riparian vegetation also may be affected. Modified from Webb and others (2007). 
can decrease the gradients to those features. Whether the case is a reduction of groundwater flow to a surface-water feature or an increase in surface-water flow to the aquifer system, there is a net loss in water in the feature. In areas where plants use groundwater (fig. 3), the cone of depression can lower the water table and reduce the uptake of water by these plants. The change in availability of water to these plants and the surfacewater features caused by a pumping well is generally referred to as "depletion" or "capture," or as "streamflow depletion" where dominant changes are decreased outflow to or increased inflow from streams and rivers. In this report, surface-water bodies including streams, springs, and wetlands and areas of vegetation that use groundwater are referred to collectively as "connected features."

The decreased outflow to and increased inflow from connected features is a source of water to the pumped well that tends to stabilize the cone of depression over time. If a well pumps for long enough at a constant rate and sufficient water can be captured from the connected features to supply the rate of water being pumped, the storage change in the aquifer from the pumping will diminish to zero and all of the water pumped by a well can be accounted for as changes in flow to or from connected features.

The time over which all or nearly all of the groundwater pumping is supplied by connected features is dependent on (1) the proximity of the pumping wells to connected features that can supply water and (2) the hydraulic properties of the aquifer. In general, wells that are close to connected features will receive water from these features much faster than more distant wells. In cases where wells are many tens of miles from connected surface water, the time at which depletion is the dominant source of water to the well can be decades or even centuries after pumping begins. A graphical example of this process is shown in figure 4. At time zero, when pumping begins, all of the water pumped is coming from storage in the aquifer. Over a period of 100 years in this example, the fraction of pumped water that comes from storage diminishes to 1 percent. The fraction of the pumping that is depletion (decrease in surface-water flow plus decrease in evapotranspiration) is the complement of the change in storage for any given time. For this example, depletion increases from zero initially to 99 percent at 100 years.

The aquifer properties that affect this timing are aquifer thickness, hydraulic conductivity, and storage coefficient. If an aquifer is dominated by horizontal flow, the relevant property that controls the rate at which pumped water is supplied from connected features is the ratio of the product of hydraulic conductivity and aquifer thickness to the storage coefficientthe hydraulic diffusivity of the aquifer. In general, higher hydraulic conductivity and aquifer thicknesses and lower storage coefficients tend to accelerate the process of depletion. The timing of effects of pumping on surface water also may be affected by complexities including heterogeneous aquifer properties, faults or other structural features that act as flow barriers or conduits, and any intervening hydrogeologic units of low vertical hydraulic conductivity that inhibit propagation of pressure changes from pumping locations at depth to connected features. These hydrogeologic complexities may slow down or speed up the process of depletion and may determine the extent to which depletion will affect certain connected features. In a groundwater system with such complexities, however, it is unreasonable to expect that groundwater pumping would never deplete connected features.

Note that effects of pumping shown in figure 4 are given as a fraction of the pumping rate. In systems that respond linearly to pumping, the fractional response at any given time

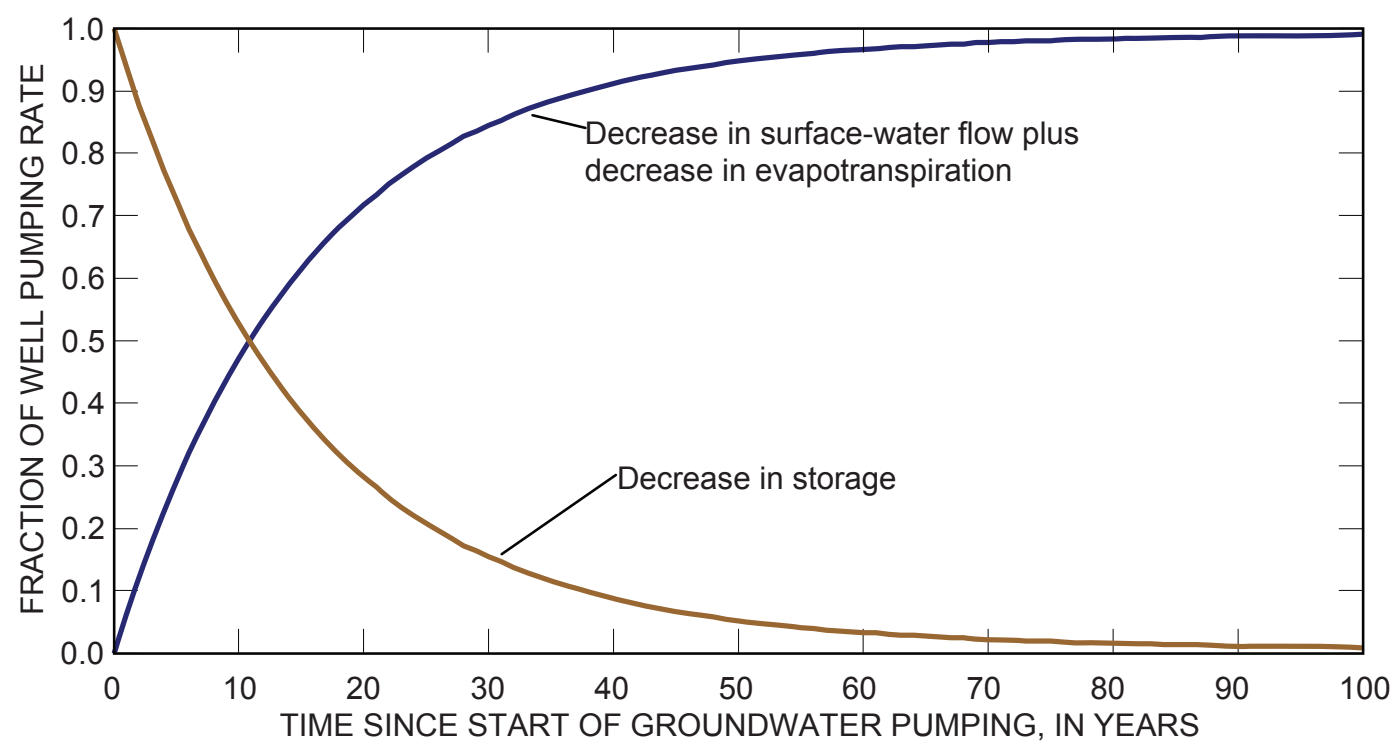

Figure 4. Sources of water to a pumped well through time. 
is independent of the pumping rate. The decrease in surfacewater flow plus reduction in evapotranspiration (uptake of groundwater by vegetation) for this example is a fraction of 0.72 or 72 percent of the pumping rate at a time of 20 years since the start of groundwater pumping. If a system responds linearly to pumping, depletion at 20 years would be $7.2 \mathrm{gal} /$ min for a well pumping $10 \mathrm{gal} / \mathrm{min}$ and would be $72 \mathrm{gal} / \mathrm{min}$ for a well pumping $100 \mathrm{gal} / \mathrm{min}$. Furthermore, in such a system the effects of pumping can be reversed to determine the effects of injecting water. If a well was injecting $100 \mathrm{gal} / \mathrm{min}$ for 20 years, for example, the increase in surface-water flow plus the increase in evapotranspiration would be $72 \mathrm{gal} / \mathrm{min}$. Nonlinearities occur when pumping (or injection of water) change the properties of the system. The most common pumping- or recharge-induced change is a large decrease or increase in saturated thickness in unconfined aquifers. Another nonlinearity occurs when pumping causes surface water or plants that use groundwater to become disconnected from the aquifer (fig 3C). Most aquifers respond linearly over some range of pumping, but become nonlinear with some level of increased pumping, especially if that pumping is concentrated in a few areas (Leake and others, 2010).

\section{The Northern Arizona Regional Groundwater- Flow Model}

The timing of effects of groundwater pumping in the Verde Valley sub-basin on connected features in and around the sub-basin can be evaluated using a groundwater-flow model. The Northern Arizona Regional Groundwater-Flow Model (NARGFM) by Pool and others (in press) is the most comprehensive and up-to-date groundwater-flow model that includes the sub-basin. With an active area of more than $51,000 \mathrm{mi}^{2}$, NARGFM simulates groundwater flow in an area much larger than the sub-basin, including parts of the Colorado Plateau, the Verde River Basin, and adjacent areas (fig. 1). Despite the large extent of the model, it is well suited to simulate conditions in the Verde Valley sub-basin because it does not include artificial head-dependent or specified-flow boundary conditions and because the uniform horizontal grid spacing of $3,281 \mathrm{ft}(1,000 \mathrm{~m})$ is appropriate for evaluating system responses to pumping in an area the size of the sub-basin.

The model was developed using the U.S. Geological Survey (USGS) groundwater model MODFLOW-2000 (Harbaugh and others, 2000) and MODFLOW-2005 (Harbaugh, 2005).

In the horizontal dimension, the model grid includes 600 rows and 400 columns of finite-difference cells. The geographic origin of the grid, at the outer corner of the cell at row 600 and column 1 is at Universal Transverse Mercator zone 12 easting $660,000 \mathrm{~m}$ and northing $3,580,000 \mathrm{~m}$. The model grid is rotated $60^{\circ}$ in the counter-clockwise direction about this point so that model columns are incremented from the cell at row 1 , column 1, to column 400 in a northeasterly direction. Similarly, rows are incremented from the cell at row 1, column 1 to row 600 in a southeasterly direction. The $60^{\circ}$ rotation is made so that rows and columns are aligned with the assumed principal directions of the hydraulic conductivity tensor. The model was constructed using units of meters for length and days for time. For this report, descriptions of values in the model are given in units of feet for length and days for time.

NARGFM uses three model layers to simulate different hydrogeologic units. The hydrogeologic units simulated within each of the three model layers vary across the model domain. For details, see Pool and others (in press). Within the Verde Valley sub-basin, the major hydrogeologic unit included in the upper model layer (layer 1) is the fluviolucustrine facies of the Verde Formation (fig. 5). The major units in the middle layer (layer 2) are the sand and gravel facies of the Verde Formation, volcanic rocks, and the upper, middle, and lower Supai Formations. The major units of the lower model layer (layer 3) are the Redwall Limestone and crystalline rock.

The active unconfined and confined model areas differ for each of the three model layers - layer 1 is active in a small area adjacent to the Verde River below Clarkdale, layer 2 is active over much of the central and eastern parts of the sub-basin, and layer 3 is active over nearly all of the sub-basin (fig. 6). Elevations of tops and bottoms of model layers were estimated from land-surface topography and geology, and any available well-log and geophysical data. Information for layer elevations is limited in undeveloped areas and at depths not penetrated by wells.

Important properties of the aquifer included in the model are hydraulic conductivity, specific storage, and specific yield.

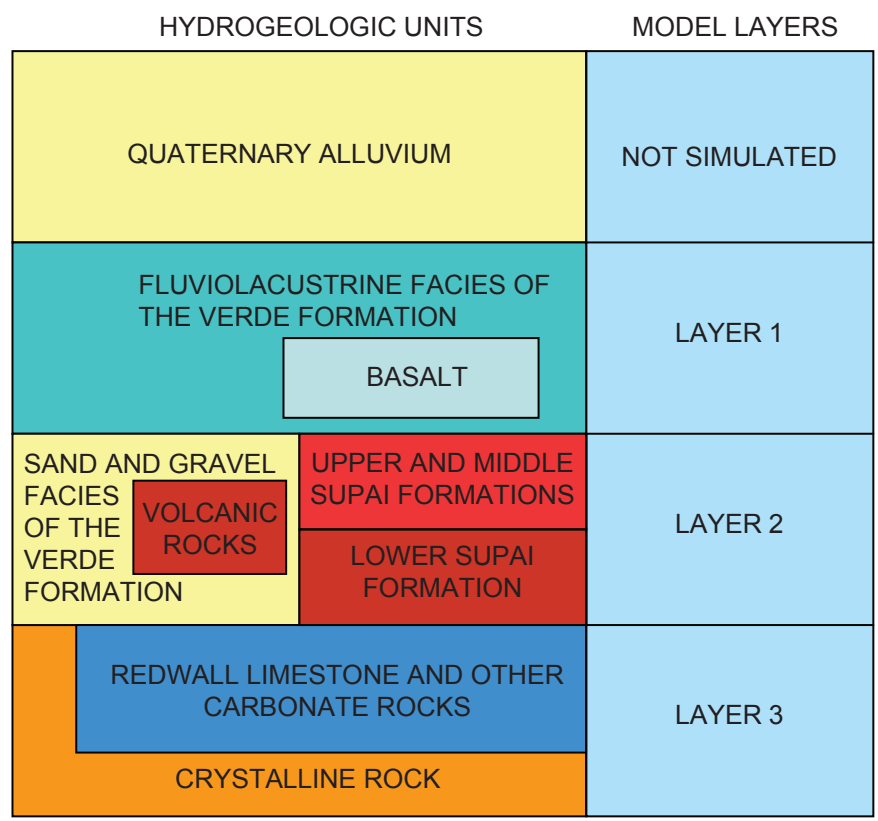

Figure 5. Conceptualized relations among hydrogeologic units and Northern Arizona Regional Groundwater-Flow Model layers in the Verde Valley sub-basin. Volcanic rocks and the lower Supai Group are confining units. Modified from Pool and others (in press). 
These are represented in the Layer-Property Flow Package of MODFLOW. Hydraulic conductivity is a tensor quantity that can be different in principal directions. In the area of the Verde Valley sub-basin in NARGFM, hydraulic conductivity is the same in both horizontal directions in layer 1 , but it is higher along columns than along rows in layers 2 and 3 (table 1). Having different hydraulic conductivity values in principal horizontal directions is referred to as "horizontal anisotropy." In this case, horizontal anisotropy represented in the model results in more resistance to groundwater movement in the northeast-southwest direction than in the northwest-southeast direction. Mean vertical hydraulic conductivity in all layers is lower than mean hydraulic conductivity along rows and columns, and is lower in layer 1 than in layers 2 and 3 (table 1). In MODFLOW, specific storage is applied where the aquifer is confined, as indicated by head or water level above the top of the aquifer. The product of specific storage and saturated thickness is the aquifer storage coefficient. The USGS has defined the storage coefficient of an aquifer as "the volume of water it releases from or takes into storage per unit surface area of the aquifer per unit change in the component of head normal to that surface" (http://water.usgs.gov/admin/memo/GW/gw55.28. $\mathrm{html}$, accessed February 7, 2010). The mechanisms for these storage changes are compression and decompression of the aquifer skeleton and water. Similarly, specific yield is applied where the aquifer is unconfined as indicated by head or water level below the top of the aquifer. Specific yield is the quantity of water released per unit unit volume of the aquifer by gravity drainage from lowering the water table. In parts of NARGFM within the Verde Valley sub-basin layer 3 that are overlain by saturated parts of layer 2 , the aquifer is confined and storage changes are calculated in the model using the product of specific storage and saturated thickness. In the remaining active part of layer 3 , the aquifer is unconfined and specific yield is used. Similarly for layer 2, the part overlain by the saturated area of layer 1 is confined and the rest of the active
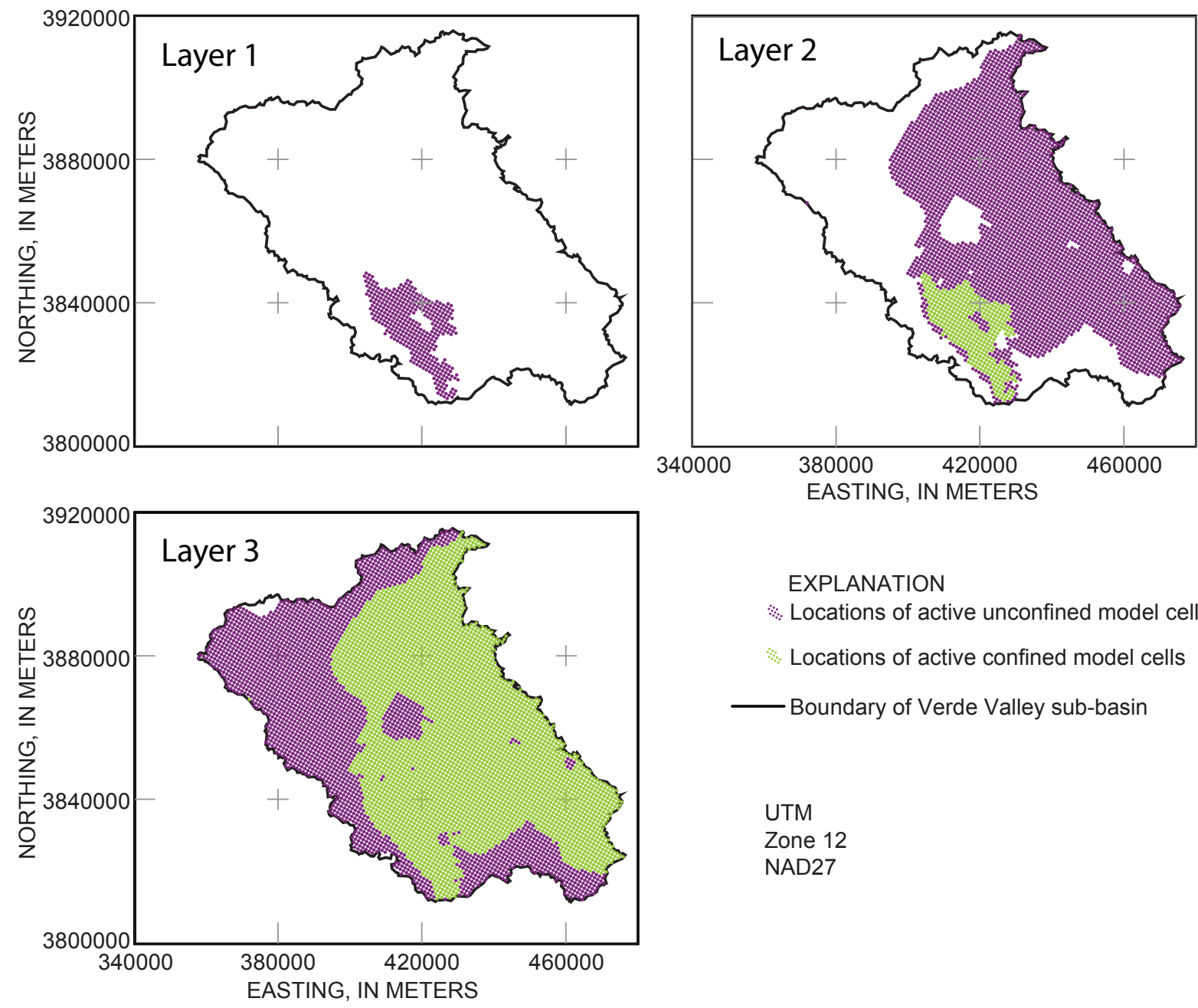

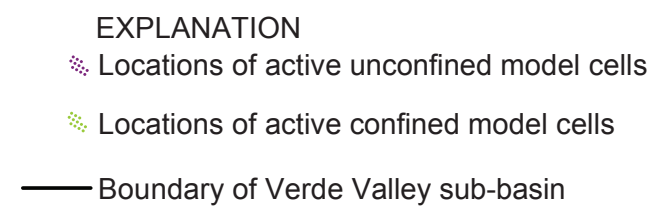

UTM

Zone 12

NAD27

Figure 6. Active unconfined and confined model cells in the Northern Arizona Regional Groundwater-Flow Model within the Verde Valley sub-basin for model layers 1, 2, and 3. 
Simulated Effects of Groundwater Pumping and Artificial Recharge in the Verde Valley Sub-Basin, Central Arizona

part is unconfined. The entire active area of layer 1 is unconfined. Mean specific yield in the sub-basin is similar in layers 1 and 2 but is an order of magnitude lower in layer 3 (table 1).

Saturated thickness also is an important factor in calculating groundwater movement in the model. Where heads are below the top of the model layer, saturated thickness is the difference between the model-calculated head or water level and the specified bottom of the aquifer. Mean saturated thickness is much larger in layers 2 and 3 than in layer 1 (table 1).

Discharge of water in NARGFM occurs through streams, simulated with the Stream Package (Prudic, 1989), and the Evapotranspiration and Drain Packages (Harbaugh, 2005). Within the Verde Valley sub-basin, two active features (springs) were simulated with the Drain Package (fig. 1) and all streams and other springs are simulated with the Stream Package. Although most connected features simulated with the Drain Package are outside of the subbasin, it is possible that some depletion could occur in these distant features from pumping in the sub-basin. Depletion from pumping in the sub-basin, however, is more likely to occur from much closer connected features within the sub-basin represented with the Stream and Evapotranspiration Packages. The Stream Package keeps track of available flow and calculates stream stage in each section or reach of stream that crosses a model cell. If leakage of water from the stream exceeds available streamflow, no further leakage is allowed from downstream reaches until the point where there is additional water available to the downstream reaches from tributary inflow or flow of groundwater into the stream. Input for the Stream Package includes specification of quantities for each of the stream reaches such as the elevations of the top and bottom of the streambed, streambed conductance, stream width, and Manning's roughness coefficient. For details on representation of features with the Stream, Drain, and Evapotranspiration Packages in the NARGFM, see Pool and others (in press).

\section{Scope}

The scope of this study includes modification of NARGFM for the purpose of studying possible effects of groundwater pumping on connected surface water and riparian plants that use groundwater. The main goal is to provide data sets and maps to support the development of sustainable water management in the Verde Valley that addresses both human needs and desired streamflow conditions. The data sets are comprehensive, including results of pumping groundwater in the Verde Valley sub-basin in all three model layers for steadystate pumping conditions, and for transient conditions during 100 years of pumping. Maps presented in this report show the effects of pumping 10 and 50 years in active parts of models layers 1 and 2. Maps showing the effects of pumping any of the model layers for any time during 100 years of pumping or for steady-state pumping conditions can be made using data sets from this study.

\section{Method}

Methods and considerations for using groundwater models to show effects of groundwater pumping or recharge on surface water and riparian vegetation are given by Leake and Reeves (2008) and Leake and others $(2008,2010)$. Similar methods were used for this study. The procedure for assessing effects of recharge on enhancement of surface flow and evapotranspiration is the same as the procedure for assessing depletion of surface-water flow and evapotranspiration, except for the directions of the forcing action (recharge to or discharge from groundwater) and response (increased or decreased surface-water flow and evapotranspiration). For simplicity, this discussion will reference the more common case of discharge (pumping) from groundwater.

The procedure used here calculates change from an assumed steady-state (predevelopment) condition. Inherent in this approach is the assumption that natural variability, such as changes in recharge, and development of groundwater resources do not greatly change the aquifer transmissivity and configuration of connected features (such as connected surface water and evapotranspiration areas). If this assumption is reasonable, then results from the method may be used to look at changes from transient conditions accompanying natural system variations and groundwater-resources development.

To use a groundwater model to assess effects of groundwater pumping on connected surface water and evapotranspiration at a location of interest, the model must first be run without the added pumping. For that run, all components of flow to and from surface-water features and evapotranspiration areas must be recorded. If the analysis is transient, water-budget components must be recorded for points in time at which effects of the added well are to be calculated.

A brief outline of the step-wise procedure used to construct the maps showing the effect of well location on the reduction of surface-water flow and (or) evapotranspiration from groundwater pumping as applied in this study follows:

1. Run the steady-state model without added pumping, and save values of groundwater flow to or from groups of stream reaches and overall groundwater discharge by riparian vegetation within the Verde Valley sub-basin.

2. For an active cell location in the sub-basin, add a well to the MODFLOW Well Package. The pumping rate is set at $18.3 \mathrm{gal} / \mathrm{min}\left(100 \mathrm{~m}^{3} / \mathrm{d}\right)$. Run a transient model with the added well for a 100 -year period.

3. At 1 -year intervals from 1 to 100 years, compute and save changes in flow components from results calculated without the well in the steadystate model (step 1). Changes in flow to and from groups of stream reaches and in discharge by riparian vegetation are divided by the well 
Table 1. Statistics of aquifer properties and saturated thickness simulated in the part of the Northern Arizona Regional Groundwater-Flow Model that underlies the Verde Valley sub-basin. Values are for active parts of each model layer.

\begin{tabular}{|c|c|c|c|c|c|}
\hline Property & Units & Statistic & Value in layer 1 & Value in layer 2 & Value in layer 3 \\
\hline \multirow[t]{3}{*}{ Hydraulic conductivity along rows } & feet per day & Mean & $5.39 \times 10^{0}$ & $2.03 \times 10^{0}$ & $1.16 \times 10^{0}$ \\
\hline & & Minimum & $3.28 \times 10^{-1}$ & $1.31 \times 10^{-2}$ & $3.28 \times 10^{-3}$ \\
\hline & & Maximum & $1.31 \times 10^{1}$ & $3.94 \times 10^{1}$ & $1.31 \times 10^{1}$ \\
\hline \multirow[t]{3}{*}{$\begin{array}{l}\text { Hydraulic conductivity along } \\
\text { columns }\end{array}$} & feet per day & Mean & $5.39 \times 10^{0}$ & $4.54 \times 10^{0}$ & $1.60 \times 10^{0}$ \\
\hline & & Minimum & $3.28 \times 10^{-1}$ & $5.91 \times 10^{-3}$ & $3.28 \times 10^{-3}$ \\
\hline & & Maximum & $1.31 \times 10^{1}$ & $1.18 \times 10^{2}$ & $6.56 \times 10^{1}$ \\
\hline \multirow[t]{3}{*}{ Vertical hydraulic conductivity } & feet per day & Mean & $2.77 \times 10^{-3}$ & $2.91 \times 10^{-2}$ & $1.16 \times 10^{-1}$ \\
\hline & & Minimum & $1.31 \times 10^{-4}$ & $1.31 \times 10^{-5}$ & $3.28 \times 10^{-4}$ \\
\hline & & Maximum & $6.56 \times 10^{-3}$ & $1.31 \times 10^{0}$ & $1.31 \times 10^{0}$ \\
\hline \multirow[t]{3}{*}{ Specific storage $^{1}$} & per foot & Mean & $3.05 \times 10^{-4}$ & $3.04 \times 10^{-5}$ & $3.05 \times 10^{-7}$ \\
\hline & & Minimum & $3.05 \times 10^{-4}$ & $3.05 \times 10^{-6}$ & $3.05 \times 10^{-7}$ \\
\hline & & Maximum & $3.05 \times 10^{-4}$ & $3.05 \times 10^{-5}$ & $3.05 \times 10^{-7}$ \\
\hline \multirow[t]{3}{*}{ Specific yield ${ }^{1}$} & - & Mean & $1.00 \times 10^{-1}$ & $1.13 \times 10^{-1}$ & $1.00 \times 10^{-2}$ \\
\hline & & Minimum & $1.00 \times 10^{-1}$ & $5.00 \times 10^{-2}$ & $1.00 \times 10^{-2}$ \\
\hline & & Maximum & $1.00 \times 10^{-1}$ & $2.50 \times 10^{-1}$ & $1.00 \times 10^{-2}$ \\
\hline \multirow[t]{3}{*}{ Saturated thickness } & Feet & Mean & $2.06 \times 10^{2}$ & $1.32 \times 10^{3}$ & $1.87 \times 10^{3}$ \\
\hline & & Minimum & $9.15 \times 10^{0}$ & $1.20 \times 10^{1}$ & $4.49 \times 10^{2}$ \\
\hline & & Maximum & $7.69 \times 10^{2}$ & $4.27 \times 10^{3}$ & $4.86 \times 10^{3}$ \\
\hline
\end{tabular}

${ }^{1}$ In computing statistics for this storage property, values at locations where the property is not used by the model were excluded.

pumping rate to get the effect of pumping as a fraction of the pumping rate. In addition to changes in flow rates at these features, the location of the well is saved.

4. When the model has been run for all desired locations of added wells, map fractions of total reduction in surface water plus reduction in evapotranspiration for the area over which calculations were made and saved.

In this procedure, steps 2-4 are repeated until results are obtained for each desired well location. In this application, wells are placed sequentially at every active model cell in the area to achieve the maximum resolution possible in mapping the effects of pumping. The horizontal grid spacing of the model is 3,281 $\mathrm{ft}(1,000 \mathrm{~m})$; therefore, sequences of steps 2-4 resulted in computed values on a horizontal grid with this spacing along the orientation of model rows and columns. Mapping for this area in step 5 includes plotting pumping-induced changes from wells in active model cells in model layers 1 and 2 in the Verde Valley sub-basin at pumping times of 10 and 50 years. From results computed and saved, different maps may be generated in the future, including pumping-induced changes from wells in any of the model layers, at any pumping time from 1 to 100 years.
The model documented by Pool and others (in press) included one steady-state stress period and nine transient stress periods. The model was not directly usable for making the steady-state model run in step 1 and the many transient model runs in step 3. Modifications made for the purposes of this study follow:

A. A steady-state model was constructed by using the first steady-state stress period in NARGFM followed by a dummy transient stress period of 1 day in length. The dummy stress period allowed direct use of the Layer-Property Flow Package input data sets from NARGFM. To maximize the mass balance of the steady-state components, closure criteria for head change and residual mass balance (input parameters HCLOSE and RCLOSE) of the Preconditioned Conjugate-Gradient solver were lowered, and the model was run with a double-precision version of MODFLOW-2005 (Harbaugh, 2005). NARGFM originally was set up with the capability of allowing rewetting of model cells during the iterative solution. The rewetting option, however, limited the accuracy of the mass balance because a number of cells would change from wet to dry and 
dry to wet on alternate iterations. For this study, the computed head and IBOUND arrays were saved from an initial solution with the rewetting option turned on. For that solution, the final status of the alternating cells was dry, or inactive. A subsequent steady-state run was made using these head and IBOUND arrays with the rewetting option turned off. In doing so, computed inflow and outflow for the revised steady-state model of about $1.27 \times 10^{7} \mathrm{ft}^{3} / \mathrm{d}$ were in agreement to within about $3 \mathrm{ft}^{3} / \mathrm{d}\left(<3.0 \times 10^{-5}\right.$ percent $)$. Computed head values from this steady-state model were saved for use as the starting head in the transient model. The implication of removing the rewetting option for the steady-state model is that certain cells with limited saturated thickness are removed from the active flow domain. These cells occur around the perimeter of the active model domain and are not important to include in the model analysis completed for this project. The transient analysis of depletion is appropriate to use without the rewetting option because there are no stresses being simulated that would cause head to rise and rewet previously dry cells.

B. NARGFM input specified locations of 1,957 drain cells. Some of these, however, were inactive in the steady-state solution because computed head was below the specified drain elevation. For this study, inactive drain cells were eliminated, resulting in 1,245 active drain cells, 2 of which are in the Verde Valley sub-basin. These remaining active cells were classified in 9 groups for which drain observations were set up to record pumping-induced change in flow for each time step using the Drain Observation Package.

C. NARGFM input included 377 segments (groups of reaches) for the Stream Package, but only 312 segments simulated flow to or from the aquifer in the steady-state model. For those 312 segments, the MODFLOW Stream Observation Package (http://water.usgs.gov/nrp/ gwsoftware/modflow2000/MFDOC/index. html, accessed Feb. 4, 2010) was used to record flows exchanged with the groundwater system. Computed flow to and from each of these stream segments was saved for the final precise steadystate model run. Components from the overall MODFLOW mass balance also were saved.

D. The transient model used in step 3 was constructed from the steady-state model by (a) using the heads from the precise steady-state run as starting heads, (b) changing the single steadystate stress period to a single transient stress period with 100 1-year time steps, (c) adding a single well as outlined in step 2, (d) computing flow values from the steady-state run for the 312 stream segments that were used as observations of interchange between the segments and the groundwater system at 1-year intervals, and (e) computing flow from the steady-state run for each of the 9 groups of drain cells that were used as observations of discharge from the groundwater system to drains at 1-year intervals. For (d) and (e), Stream and Drain Observation Packages were used. The transient model also was run with a double-precision version of MODFLOW-2005. In using the steady-state values of flow to or from stream reaches as observations, calculated differences between computed and observed flows are the direct effect of the added pumping well.

In addition to the procedure described above for calculating the effects of pumping through time since pumping began, the effects of the new steady-state condition (when storage change is zero and all of the water pumped is from reduced surface water and reduced evapotranspiration) were calculated, regardless of the time required to reach this condition. This steady-state approach is useful in evaluating effects on multiple connected features. For example, if a system included stream A and stream B, pumping at some locations (presumably near stream A) would tend to ultimately affect only stream A by the amount of the well pumping rate. For other locations, pumping would affect both streams, with the sum of the effect on each stream equal to the total pumping rate (where depletion from features simulated with the Evapotranspiration and Drain Packages are zero). The procedure for carrying out the steady-state analysis is similar to that for the transient analysis outlined above, except that the transient model in step 3 is replaced with a steady-state model. Instead of effects at 1-year intervals up to 100 years, this model calculates a single ultimate effect when steady-state conditions under the imposed pumping stress are reached, without any indications of how many years, decades, or centuries it might take to reach that condition.

\section{Results}

In model layers 1, 2, and 3, pumping from a single hypothetical well was simulated sequentially in each of 10,789 active model cells. This was achieved by running the model 10,789 times. The repeated model runs produced a variety of results, only a small subset of which is presented in this report. All results are depletion values, expressed as a fraction of the pumping rate for each of 10,789 active model cells in layers 1-3 in the Verde Valley sub-basin. Most transient results include depletion values at 1-year intervals from 1-100 years for each cell and steady-state results include a single ultimate depletion value for each cell.The complete results of model runs include the following: 
1. Total reduction in streamflow (simulated with the Stream and Drain Packages) plus total reduction in evapotranspiration, simulated in the transient model.

2. (a) Rate of change in groundwater storage, (b) reduction in outflow to features simulated with the Drain Package, (c) reduction in outflow to features simulated with the Evapotranspiration Package, and (d) reduction of net flow between the aquifer and features simulated with the Stream Package at 100 years, simulated in the transient model.

3. Total reduction in streamflow for each of 312 stream segments, simulated in the transient model.

4. Total reduction in streamflow for each of 312 stream segments, simulated in the steady-state model.

5. Total reduction in groundwater outflow for each of 9 groups of drain cells, simulated in the transient model.

6. Total reduction in groundwater outflow for each of 9 groups of drain cells, simulated in the steady-state model.

These results are in ASCII files archived with the models used for this study and are available upon request.

By assuming linearity in response to pumping, results in item 1 can be used to compute effects of more complex scenarios than a single well pumping at a constant rate for a period of time. To compute additive effects, fractions in item 1 must be first multiplied by pumping rates to calculate actual depletion. For given times, actual depletions from different pumping locations may be added to calculate the total depletion from all of the pumping locations. It is also possible to compute the effects of pumping at a variable rate at a single well location, including the effects of a well that is pumped intermittently. For example, data from the curve of reduced surface-water flow and evapotranspiration shown in figure 4 may be used to compute absolute effects for a well that pumps 30 acre-ft per year for years $1-5$ and then for years 6-10 the pumping rate continues (case 1), stops (case 2), and doubles (case 3). The fractions that make up the curve for times 0-10 years in figure 4 are designated as line 1 in table 2. For case 1 , fractions in line 1 are multiplied by $30 \mathrm{acre-ft} / \mathrm{year}$ to compute values in line 2, the absolute reduction in surface-water flow and evapotranspiration, in acre-ft/yr, that would result from this well pumping at a constant rate for 1-10 years. To obtain the effects of a change in pumping rate at 5 years, the pumping rates for times $1-5$ years must be put into the positions of times 6-10 years as shown in line 3 in table 2 . These values are equivalent to responses from a hypothetical well at this location that counteracts the pumping of the existing well for case 2 or adds to the pumping rate of the existing well for case 3 . For case 2, values in line 3 are subtracted from values in line 2 to calculate the response for the well ceasing to be pumped, and for case 3 , values in line 3 are added to values in line 2 to calculate the response for a doubling of the pumping rate (table 2, fig. 7).

In addition to these results, some information was generated to indicate possible nonlinearity for each of the 10,789 pumping locations. This included a code to denote where pumping caused the cell being pumped to go dry and the number of stream reaches (sections of streams that cross a model cell), if any, for which the connection to the aquifer became nonlinear because of the added well pumping $18.3 \mathrm{gal} / \mathrm{min}$. Dry pumping cells occurred mostly around the margins of the active part of model layer 1 and in some locations in model layer 2 where initial saturated thickness was low. Nonlinear

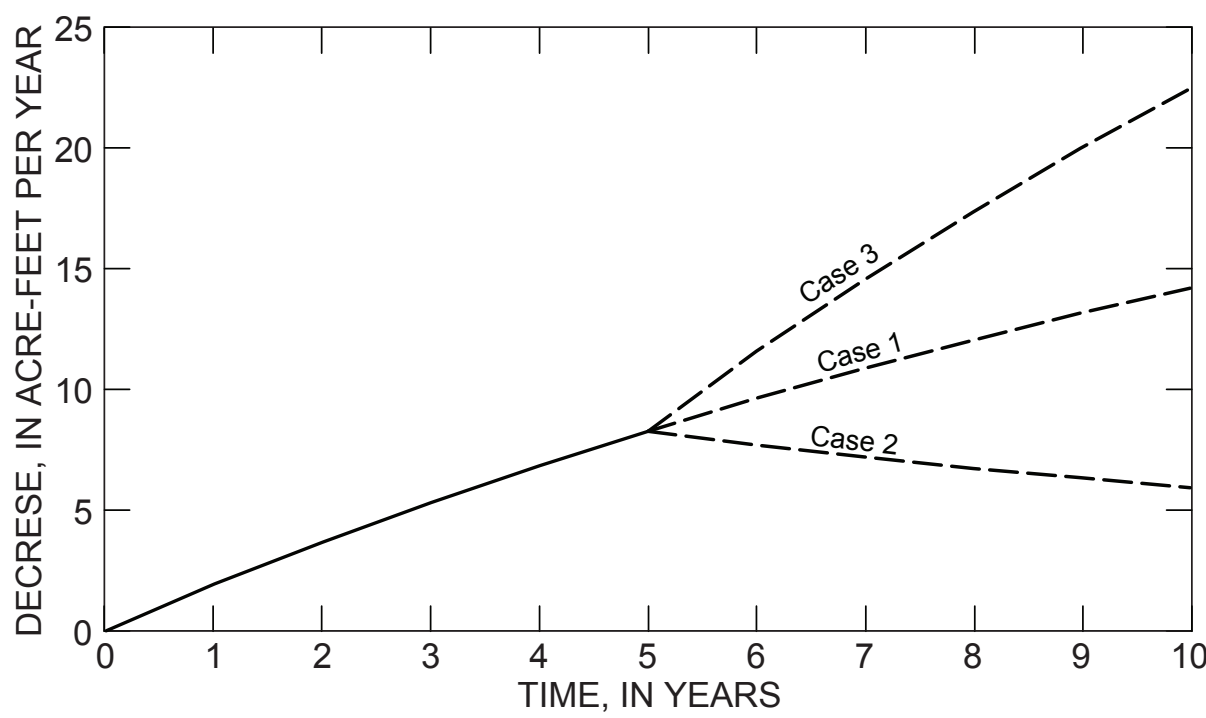

Figure 7. Decrease in surface-water flow and evapotranspiration for the example shown in figure 4 for a well that pumps 30 acre-feet per year for years 1-5; then for years $6-10$ the pumping rate continues (case 1), stops (case 2), and doubles (case 3). 
Table 2. Example calculations of absolute depletion from depletion fractions for a well that pumps 30 acre-feet per year for years $1-5$, and then continues pumping at that rate for years $6-10$ (case 1), shuts off for years 6-10 (case 2), and doubles in pumping rate for years $6-10$ (case 3 ).

[Results for case 1, years $0-10$, are shown in line 2; results for case 2, years 6-10, are shown in the last five columns of line 4; results for case 3, years 6-10, are shown in the last five columns of line 5.]

\begin{tabular}{|c|c|c|c|c|c|c|c|c|c|c|c|c|}
\hline \multirow{2}{*}{$\begin{array}{l}\text { Line } \\
\text { number }\end{array}$} & \multirow[t]{2}{*}{ Item } & \multicolumn{11}{|c|}{ Result } \\
\hline & & 0 & 1 & 2 & 3 & 4 & 5 & 6 & 7 & 8 & 9 & 10 \\
\hline 1 & $\begin{array}{l}\text { Depletion fractions } \\
\text { from first } 10 \text { years } \\
\text { of graph shown in } \\
\text { figure } 4\end{array}$ & 0.00 & 0.06 & 0.12 & 0.18 & 0.23 & 0.28 & 0.32 & 0.36 & 0.40 & 0.44 & 0.47 \\
\hline 2 & $\begin{array}{c}\text { Values in line } 1 \text { times } \\
\text { pumping rate of } 30 \\
\text { acre-feet per year }\end{array}$ & 0.00 & 1.94 & 3.68 & 5.31 & 6.84 & 8.26 & 9.64 & 10.88 & 12.04 & 13.18 & 14.19 \\
\hline 3 & $\begin{array}{l}\text { Values from years } \\
0-5 \text { in line } 2 \text { put } \\
\text { into columns for } \\
\text { years } 5-10\end{array}$ & 0.00 & 0.00 & 0.00 & 0.00 & 0.00 & 0.00 & 1.94 & 3.68 & 5.31 & 6.84 & 8.26 \\
\hline 4 & $\begin{array}{l}\text { Values in line } 2 \text { minus } \\
\text { values in line } 3\end{array}$ & 0.00 & 1.94 & 3.68 & 5.31 & 6.84 & 8.26 & 7.69 & 7.20 & 6.72 & 6.34 & 5.93 \\
\hline 5 & $\begin{array}{l}\text { Values in line } 2 \text { minus } \\
\text { values in line } 3\end{array}$ & 0.00 & 1.94 & 3.68 & 5.31 & 6.84 & 8.26 & 11.58 & 14.55 & 17.35 & 20.02 & 22.45 \\
\hline
\end{tabular}

connection between stream reaches and the aquifer can occur for two conditions. The first condition occurs when leakage of water to the aquifer is limited by available streamflow and the second condition occurs when aquifer head falls below the specified streambed bottom elevation and leakage to the aquifer becomes steady. At a simulation time of 100 years, one or both of these conditions occurred at 1 stream reach for 22 pumping locations and at 2 stream reaches for 33 pumping locations. Further analysis of nonlinearity would require recomputing effects at all locations with different pumping rates. Such analyses are beyond the scope of this study.

Results presented here for pumping locations in model layers 1 and 2 show the fraction of the $18.3 \mathrm{gal} / \mathrm{min}$ pumping rate that is computed to be a reduction in surface-water flow and evapotranspiration after 10 and 50 years since the onset of pumping. Results for model layer 1 at 10 years (fig. 8) indicate that the greatest effects occur along the Verde River between Clarkdale and Cottonwood and from several miles upstream of Camp Verde to the sub-basin boundary. Values also are higher along Oak Creek upstream and downstream from Cornville. Values are lower along the Verde River along an 11-mile reach of the river below Cottonwood. Results for model layer 1 at 50 years (fig. 9) indicate similar patterns of higher and lower values but with higher fractions of decrease in surface-water flow and evapotranspiration because of the longer pumping time. Nonetheless, model results show fractions of reduction in flow and evapotranspiration of less than 0.1 (10 percent of the pumping rate) at 50 years for some areas along the north and west edges of the active part of model layer 1 (fig. 9).

Fractions of reduced surface-water flow and evapotranspiration for pumping locations in model layer 2 at 10 years (fig. 10) indicate highest responses along the Verde River upstream of Cottonwood and downstream of Camp Verde, along reaches of Oak Creek, and along Wet Beaver Creek upstream of Rimrock. Only the most upper and lower parts of West Clear Creek are connected to model layer 2. These results, therefore, do not indicate effects of groundwater pumping on most of West Clear Creek. Results for model layer 2 at 50 years (fig. 11) indicate general increases in effects along the surface-water features and at greater distances from these features, compared to results at 10 years. A complex pattern of lower response exists in part of this area overlain by model layer 1, east and west of Cornville. Patterns of response generally are correlated with properties such as hydraulic conductivity. For example, some of the highest areas of depletion from pumping in model layer 2 are in areas were hydraulic conductivity along rows is greater than $5 \mathrm{ft} / \mathrm{d}$ (figs. 10-11). Other high areas are adjacent to streams.

In addition to evaluating possible effects of groundwater pumping, figures 8-11 also can be used to understand the effects of managed recharge on surface-water flow and evapotranspiration. For recharge at a constant rate, areas with higher fractions (orange and red) for a given time indicate a greater enhancement of surface-water flow and evapotranspiration 


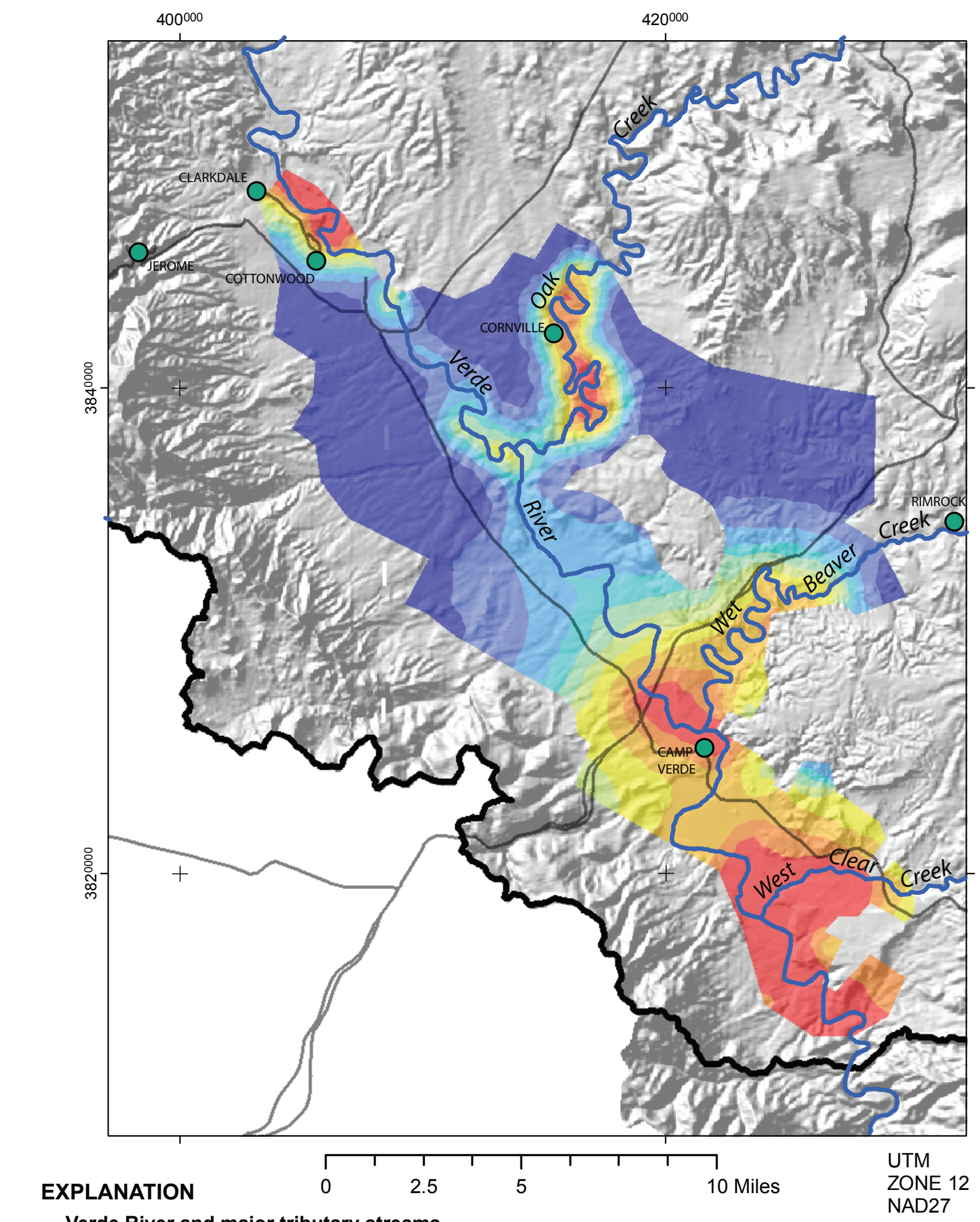

Verde River and major tributary streams

Major Roads

$\square$ Verde Valley sub-basin
Total reduced flow as a fraction of pumping rate at 10 years

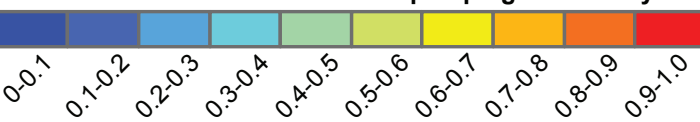

Figure 8. Computed reduction in flow of streams and springs and reduction in riparian evapotranspiration as a fraction of pumping rate that would result from pumping groundwater from model layer 1 at a constant rate for 10 years. The color at any location represents the fraction of the pumping rate by a well at that location that can be accounted for as changes in outflow from or inflow to the aquifer for model boundaries representing steams, riparian vegetation and springs. 


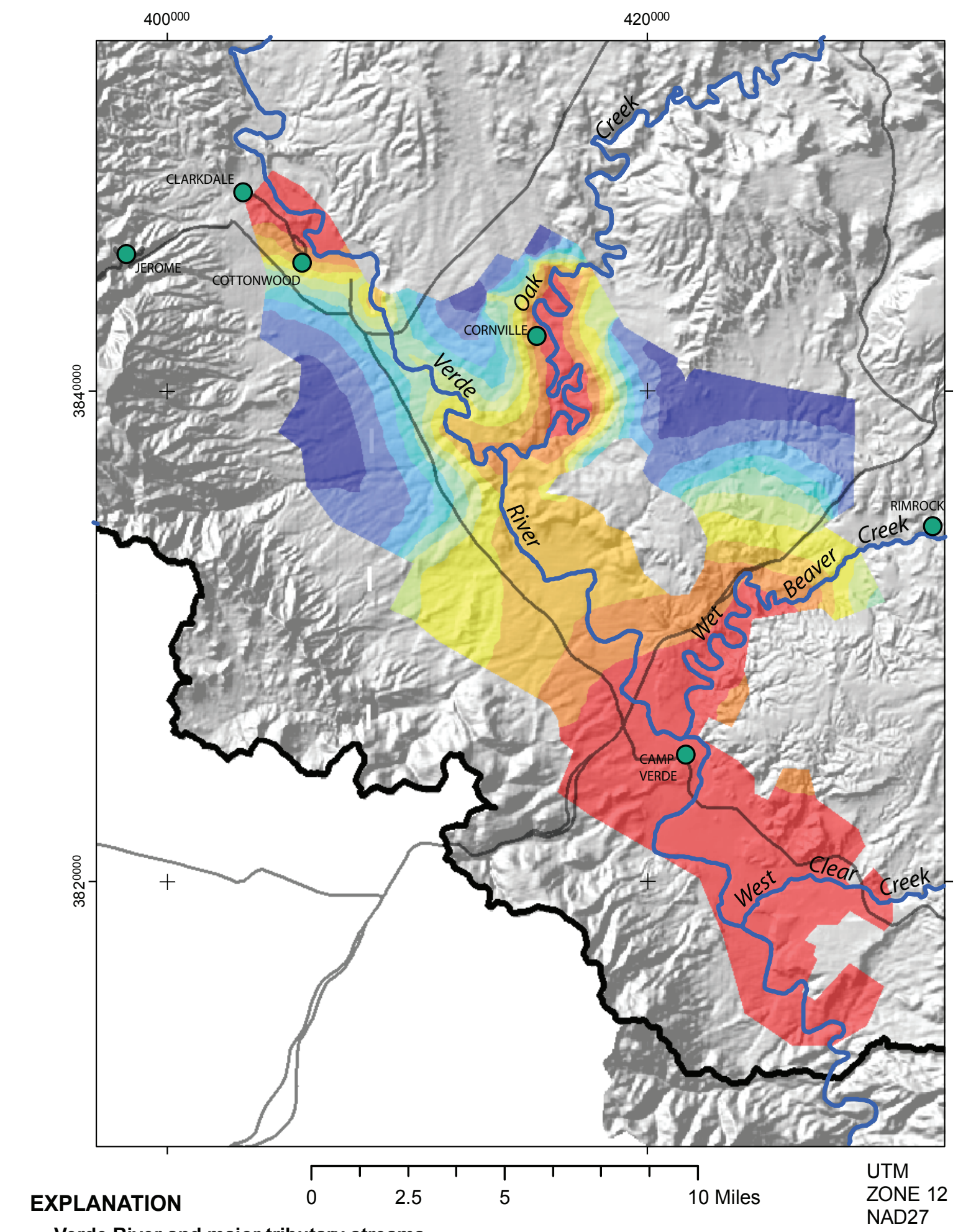

Verde River and major tributary streams

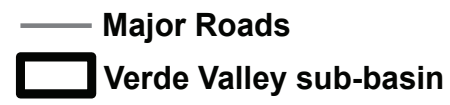

Total reduced flow as a fraction of pumping rate at $\mathbf{5 0}$ years

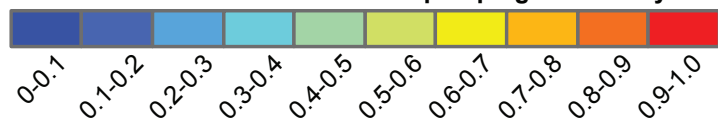

Figure 9. Computed reduction in flow of streams and springs and reduction in riparian evapotranspiration as a fraction of pumping rate that would result from pumping groundwater from model layer 1 at a constant rate for 50 years. The color at any location represents the fraction of the pumping rate by a well at that location that can be accounted for as changes in outflow from or inflow to the aquifer for model boundaries representing streams, riparian vegetation and springs. 
than areas with lower fractions (blues). If recharge is by gravity drainage to the water table, results from confined parts of model layers 2 and 3 should not be used.

The relative contributions to total depletion from features simulated with the Drain, Evapotranspiration, and Stream Packages after 100 years can be seen in results $2 b-d$ listed above. Average values of depletion by type of feature and by model layer (table 3 ) indicate that most of the depletion occurs in features represented with the Stream Package for pumping in all model layers.

\section{Applicability and Limitations}

As indicated by Leake and others (2008), the procedure used for the analysis described in this report was designed to depict responses to pumping or recharge over large areas of an aquifer. The results are meant to help resource managers and the general public understand patterns of responses that are based on features represented in the part of the NARGFM underlying the Verde Valley sub-basin. The distributions shown on figures 8-11 do not necessarily mean that groundwater pumping and (or) recharge to the aquifer at all locations is appropriate or even technically feasible. In the generation of maps presented in this report, an automated procedure computed effects at all active model cells regardless of properties such as hydraulic conductivity and storage coefficient. For site-specific projects involving groundwater pumping or recharge to the aquifer, improved results may require detailed studies of the local hydrologic conditions and a refinement of the modified NARGFM in the area of interest.

As discussed previously, results are independent of the pumping or recharge rate if the system responds linearly to these changes. Although comprehensive testing of linearity was not done for this study, other withdrawal rates should produce patterns of fractions of decrease in surface-water flow and evapotranspiration that are similar to those shown in figures $8-11$, particularly for pumping or recharge rates that are smaller than the rate of $18.3 \mathrm{gal} / \mathrm{min}$ used in this analysis. For example, with higher pumping rates, there is an increased likelihood of nonlinearity from reducing saturated thicknesses, from drying stream reaches, and from lowering water levels below the evapotranspiration extinction depth. Changes are most likely to occur in areas where saturated thickness is lowest and near streams where base flow is sufficiently low to be entirely depleted by the pumping. If nonlinearity exists, it will affect the timing of effects on surface-water flow and evapotranspiration, but nonlinearities will not change the tendency towards the ultimate effect of the entire pumping rate being accounted for as reduction in surface-water flow and evapotranspiration. If nonlinearities exist, responses to pumping rates higher than $18.3 \mathrm{gal} / \mathrm{min}$ will be overestimated by results in this report, and responses to higher recharge rates will be underestimated.

The analyses use a constant pumping rate for a period of 100 years. In reality, wells are not managed to pump at a
Table 3. Average depletion after 100 years of pumping expressed as a fraction of the pumping rate for features simulated with the Drain, Evapotranspiration, and Stream Packages, for pumping locations in layers 1,2 , and 3.

\begin{tabular}{ccccc}
\hline Layer & $\begin{array}{c}\text { Drain } \\
\text { Package }\end{array}$ & $\begin{array}{c}\text { Evapotranspiration } \\
\text { Package }\end{array}$ & $\begin{array}{c}\text { Stream } \\
\text { Package }\end{array}$ & $\begin{array}{c}\text { Number } \\
\text { of } \\
\text { solutions }\end{array}$ \\
\hline 1 & $2.41 \times 10^{-4}$ & $8.34 \times 10^{-2}$ & $6.93 \times 10^{-1}$ & 384 \\
2 & $6.17 \times 10^{-4}$ & $1.12 \times 10^{-2}$ & $3.44 \times 10^{-1}$ & 3,959 \\
3 & $2.39 \times 10^{-2}$ & $1.11 \times 10^{-2}$ & $5.21 \times 10^{-1}$ & 6,037 \\
\hline
\end{tabular}

constant rate, but rather are pumped in response to demands for water. The responses in this study approximate the response for a well location in which a time-average of the variable rate of pumping is used as a constant rate of pumping. In areas where substantial depletion of surface water and evapotranspiration occurs more quickly (for example in the red areas of figures 8 and 10), approximation of effects with a time-averaged rate might not represent the possible maximum depletion of surface water and evapotranspiration. If more exact responses are needed for cyclical or intermittent pumping, the procedure for more complex scenarios described above (table 2, fig. 7) may be applied. The use of 1-year time steps for this analysis, however, limits operational periods to multiples of 1-year. Analysis of shorter periods would require interpolation of model results from this study, or a separate study.

\section{Summary}

In the Verde Valley sub-basin, groundwater is the primary source of domestic and municipal supply. Groundwater use has increased in recent decades and a better understanding of the effects of groundwater pumping and managed recharge on surface water and groundwater-dependent riparian vegetation is needed. The Northern Arizona Regional Groundwater-Flow Model by Pool and others (in press) is the most comprehensive and up-to-date tool available to understand the effects of groundwater pumping in the sub-basin. For this study, the model was modified to calculate the combined effect of reduced surface-water flow and evapotranspiration from groundwater pumping for locations in the sub-basin where model cells were active. The procedure by Leake and others (2008) was used to run the model repeatedly, each time with a single pumping well in a different location for each active model cell. For each location, effects of the single well on surface-water flow and evapotranspiration were calculated and saved. Results for pumping times of 10 and 50 years for locations in active parts of model layers 1 and 2 were used to map total reduced surface-water flow and evapotranspiration as a fraction of pumping rate after 10 and 50 years (figs. $8-11$ ). These results also can be used to evaluate response of surface-water flow and evapotranspiration to recharge at a 


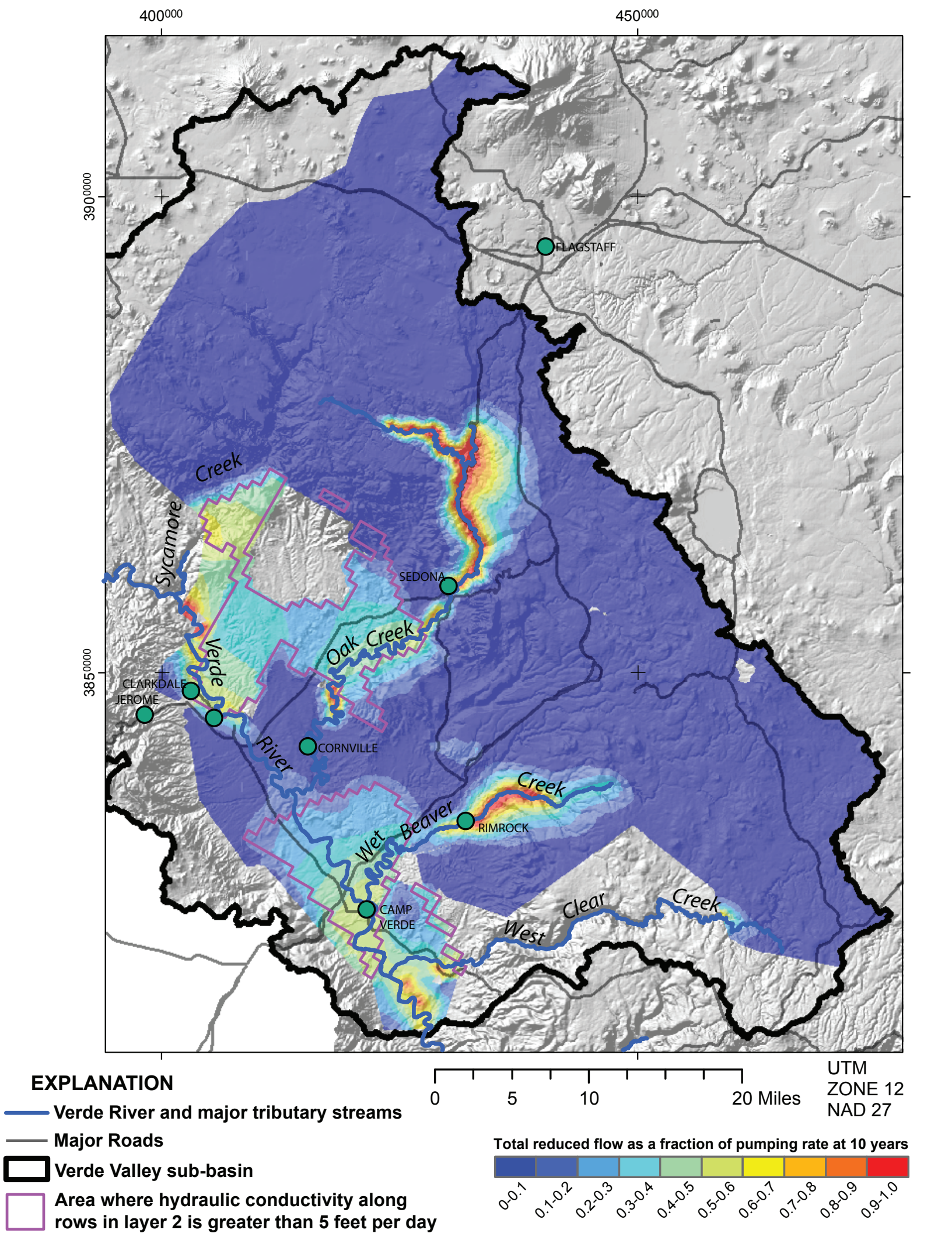

Figure 10. Computed reduction in flow of streams and springs and reduction in riparian evapotranspiration as a fraction of pumping rate that would result from pumping groundwater from model layer 2 at a constant rate for 10 years. The color at any location represents the fraction of the pumping rate by a well at that location that can be accounted for as changes in outflow from or inflow to the aquifer for model boundaries representing streams, riparian vegetation and springs. 


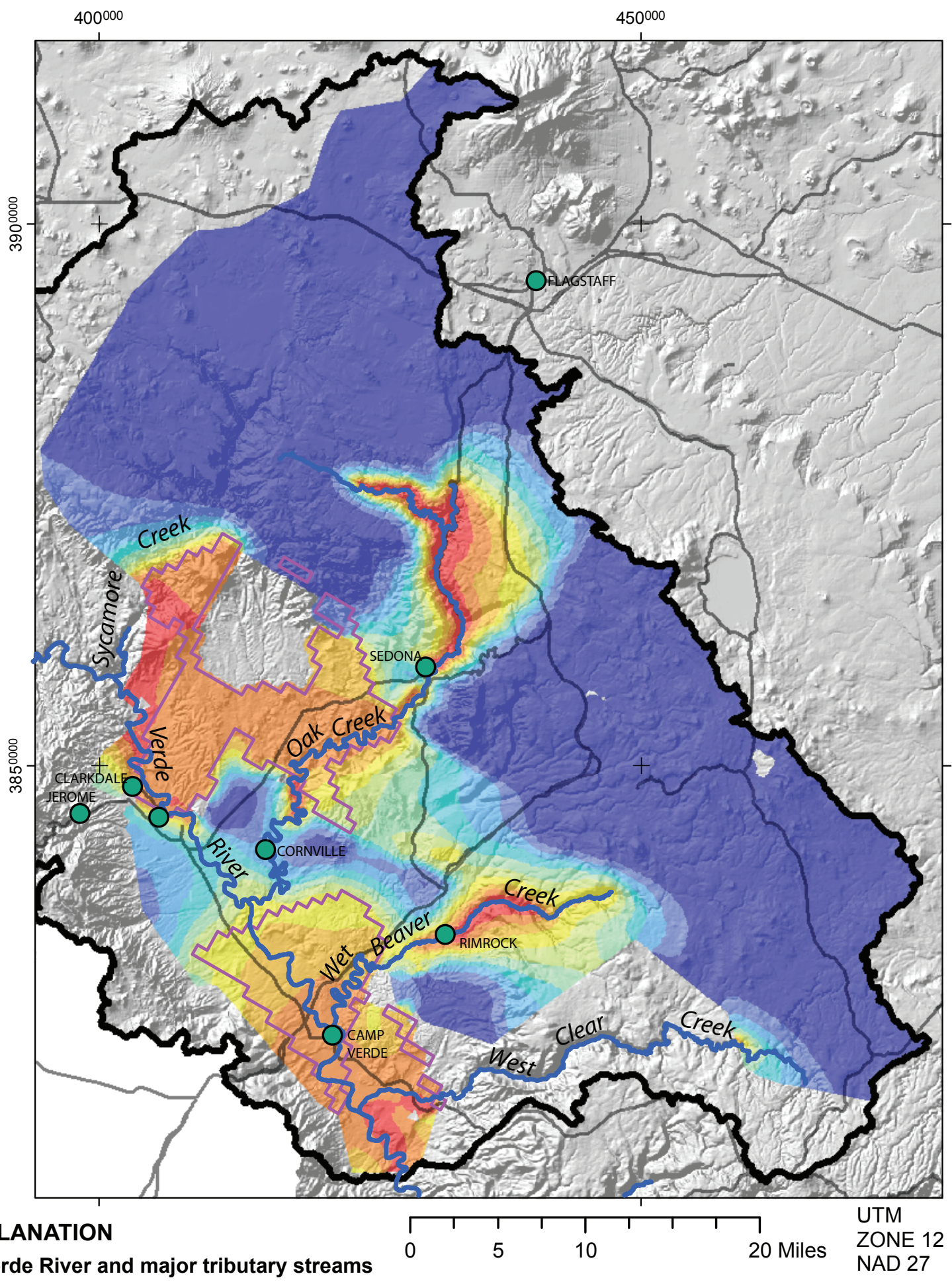

Verde River and major tributary streams

Major Roads

Verde Valley sub-basin

Area where hydraulic conductivity along rows in layer $\mathbf{2}$ is greater than 5 feet per day

Total reduced flow as a fraction of pumping rate at $\mathbf{5 0}$ years

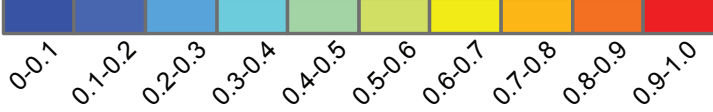

Figure 11. Computed reduction in flow of streams and springs and reduction in riparian evapotranspiration as a fraction of pumping rate that would result from pumping groundwater from model layer 2 at a constant rate for 50 years. The color at any location represents the fraction of the pumping rate by a well at that location that can be accounted for as changes in outflow from or inflow to the aquifer for model boundaries representing streams, riparian vegetation and springs. 
constant rate. The highest and most rapid simulated responses to pumping occurred near surface-water features simulated in the model, but results were not uniform along these features. For example, higher responses for pumping times of 10 and 50 years for locations in both layers 1 and 2 were calculated adjacent to the Verde River upstream of Cottonwood and from the Camp Verde area to the boundary of the sub-basin. Responses along the intermediate part of the Verde River at these times were lower. The results shown in figures 8-11 indicate general patterns over large areas, as computed by the modified model. Investigations of pumping or recharge at specific sites may require more detailed study.

\section{Acknowledgments}

Jeanmarie Haney and Brenda Burman of The Nature Conservancy, Arizona, provided valuable insights on the types of model results that would support the evaluation of water management strategies in the Verde Valley sub-basin. Thoughtful reviews by Steve Peterson and Nora Herrera of the USGS, and Jeanmarie Haney greatly improved the report.

\section{References Cited}

Blasch, K.W., Hoffmann, J.P., Graser, L.F., Bryson, J.R., and Flint, A.L., 2006, Hydrogeology of the upper and middle Verde River watersheds, central Arizona: U.S. Geological Survey Scientific Investigations Report 2005-5198, 102 p., 3 plates, accessed July 14, 2010, at http://pubs.usgs.gov/sir/2005/5198/.

Harbaugh, A.W., 2005, MODFLOW-2005, the U.S. Geological Survey modular ground-water model -- the GroundWater Flow Process: U.S. Geological Survey Techniques and Methods 6-A16, variously p. accessed July 14, 2010, at http://pubs.usgs.gov/tm/2005/tm6A16/.

Harbaugh, A.W., Banta, E.R., Hill, M.C., and McDonald, M.G., 2000, MODFLOW-2000, the U.S. Geological Survey modular ground-water model-user guide to modularization concepts and the ground-water flow process: U.S. Geological Survey Open-File Report 00-92, 121 p. accessed July 14, 2010, at http://water.usgs.gov/nrp/gwsoftware/modflow 2000/ofr00-92.pdf.
Leake, S.A., Pool, D.R., and Leenhouts, J.M., 2008, Simulated effects of ground-water withdrawals and artificial recharge on discharge to streams, springs, and riparian vegetation in the Sierra Vista Subwatershed of the Upper San Pedro Basin, southeastern Arizona: U.S. Geological Survey Scientific Investigations Report 2008-5207, 14 p. accessed July 14, 2010, at http://pubs.usgs.gov/sir/2008/5207/.

Leake, S.A., and Reeves, H.W., 2008, Use of models to map potential capture of surface water by ground-water withdrawals: Golden, Colorado, International Groundwater Modeling Center, Proceedings of MODFLOW and More 2008, p. 204-208.

Leake, S.A., Reeves, H.W., and Dickinson, J.E., 2010, A new capture fraction method to map how pumpage affects surface water flow: Ground Water, doi: 10.1111/j.17456584.2010.00701.x, 11 p.

Pool, D. R., Blasch, K.W., Callegary, J., and Glaser, L., in press, Groundwater-flow model of the Redwall-Muav, Coconino, and Alluvial Basin aquifer systems of northern and central Arizona: U.S. Geological Survey Scientific Investigations Report 2010-5180.

Prudic, D.E., 1989, Documentation of a computer program to simulate stream-aquifer relations using a modular, finite-difference, ground-water flow model: U.S. Geological Survey Open-File Report 88-729, 113 p.

Stonestrom, D.A., Constantz, J., Ferré, T.P.A., and Leake, S.A., eds., 2007, Ground-water recharge in the arid and semiarid southwestern United States: U.S. Geological Survey Professional Paper 1703, 414 p. accessed July 14, 2010, at http://pubs.usgs.gov/pp/pp1703/.

Webb, R.H., Leake, S.A., and Turner, R.M, 2007, The ribbon of green - change in riparian vegetation in the Southwestern United States: Tucson, University of Arizona Press, 480 p.

Winter, T.C., Harvey, J.W., Franke, O.L., and Alley, W.M., 1998, Ground water and surface water - a single resource: U.S. Geological Survey Circular 1139, 79 p. accessed July 14, 2010, at http://pubs.usgs.gov/circ/circ1139/. 
Produced in the Western Region, Menlo Park, California Manuscript approved for publication Text edited by Jan Zigler Layout and design by Judy Weathers 

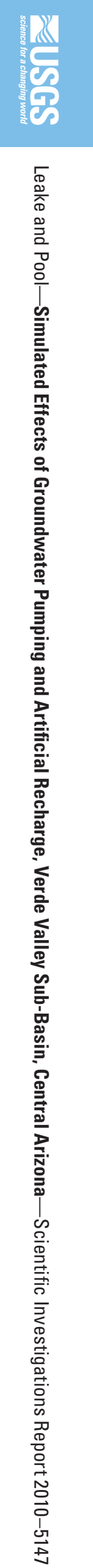